"Mircea cel Batran" Naval Academy Scientific Bulletin, Volume XX - 2017 - Issue 1

The journal is indexed in: PROQUEST / DOAJ / Crossref / EBSCOhost / INDEX COPERNICUS / DRJI / OAJI I

JOURNAL INDEX I I2OR / SCIENCE LIBRARY INDEX / Google Scholar / Academic Keys/ ROAD Open Access I

Academic Resources / Scientific Indexing Services / SCIPIO / JIFACTOR

\title{
THE DYNAMIC DESIGN OF THE MARIN ENGINES
}

\section{Corneliu MOROIANU}

${ }^{1}$ Ph. D. The Naval Academy "Mircea cel Bătrân" Constanța Email address: cmoroianu2000@yahoo.com

Abstract: The study of the stresses in the drive mechanism takes into account the determination of forces and moments loading the drive mechanism. Depending on the physical phenomenon inducing the forces in the drive mechanism, we have: pressure forces, inertia forces, friction forces and gravity forces. Practically speaking, the determination of the pressure and inertia forces presents a special importance and the other two forces are much smaller. This paper presents a numerical method for determining the stresses by means of the E-FORT program with MATHCAD as a mathematical interpreter.

Key words: drive mechanism, stress, pressure, inertia, friction and gravity forces.

\section{INTRODUCTION}

The study of the stresses in the drive mechanism takes into account the determination of forces and moments loading the drive mechanism.

Depending on the physical phenomenon inducing the forces in the drive mechanism, we mark out:

a. The pressure forces: are induced by the motive fluid inside the cylinder;

b. The inertia forces: are induced by the increasing motions of the drive mechanism part masses;

c. The friction forces: are induced by the drive mechanism part motions and the forces passing over between them;

d. The gravity forces: are induced by the gravitational field acting on the drive mechanism part masses.

Practically speaking, the determination of the pressure and inertia forces presents a special importance and the other two forces are much smaller; we shall go on with the determination of the calculation relations for the pressure and inertia forces.

The pressure force applied on the piston top The values of the gas pressure force have been calculated by equation (1). On these values, the pressure force curve is represented, Fig. 1.

$\mathrm{F}_{\mathrm{p}}=\frac{\pi \cdot \mathrm{D}^{2}}{4} \cdot\left(\mathrm{p}-\mathrm{p}_{\mathrm{cart}}\right)[\mathrm{N}]$

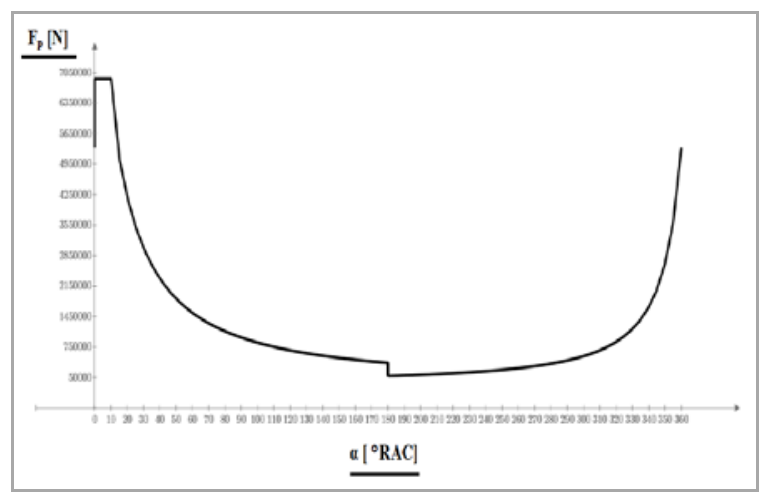

Fig. 1. - The pressure force curve.

\section{THE INERTIA FORCE OF MASSES WITH A TRANSLATION MOTION}

The determination of inertia force of masses with a translation motion:

$$
\mathrm{F}_{\mathrm{it}}=-\mathrm{m}_{\mathrm{it}}{ }^{*} \mathrm{a}_{\mathrm{p}}[\mathrm{N}]
$$

Where:

$$
\begin{aligned}
& \quad \mathrm{m}_{\mathrm{it}}=\mathrm{m}_{\mathrm{p}}+\mathrm{m}_{\mathrm{tp}}+\mathrm{m}_{\mathrm{bp}}+\mathrm{m}_{\mathrm{cc}} \\
& \mathrm{m}_{\mathrm{p}} \text { - piston mass [kg], } \\
& \mathrm{m}_{\mathrm{tp}}-\text { branch rod mass }[\mathrm{kg}] \\
& \mathrm{m}_{\mathrm{bp}}-\text { mass of the connecting-rod related to }
\end{aligned}
$$
the piston $[\mathrm{kg}]$,

$\mathrm{m}_{\mathrm{cc}}-$ crosshead mass $[\mathrm{kg}]$.

For the decomposition of the connecting-rod mass into the mass of the connecting-rod related to the piston and the mass of the connecting-rod related to the crankpin on the figure 2 , we shall calculate the gravity center of the connecting-rod.

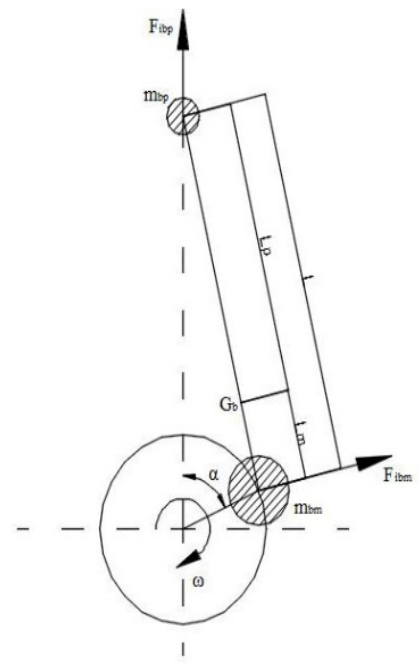

Fig.2. - The decomposition of the connecting-rod mass into the masses related to the piston, respectively, the crankpin.

The gravity center of the connecting-rod is determined by V.P.Terskih: 
"Mircea cel Batran" Naval Academy Scientific Bulletin, Volume XX - 2017 - Issue 1

The journal is indexed in: PROQUEST / DOAJ / Crossref / EBSCOhost / INDEX COPERNICUS / DRJI / OAJI I

JOURNAL INDEX I I2OR / SCIENCE LIBRARY INDEX / Google Scholar I Academic Keys/ ROAD Open Access I Academic Resources / Scientific Indexing Services / SCIPIO / JIFACTOR

$\frac{L m}{L}=0,2 \cdot \frac{(0,001 \cdot n)^{2}+2}{(0,0 D 1 \cdot n)^{2}+1}$

The mass of the connecting-rod related to the piston:

$$
\mathrm{m}_{\mathrm{bp}}=\mathrm{m}_{\mathrm{b}}=\frac{\mathrm{L}_{\mathrm{m}}}{\mathrm{L}}[\mathrm{kg}]
$$

The mass of the connecting-rod related to the crankpin:

$$
m_{b m}=m_{b}-m_{b p}[k g] \text {. }
$$

The total mass of the parts with a translation motion:

$$
m_{\text {itt }}=m_{p}+m_{t p}+m_{b p}+m_{c e c}[\mathrm{~kg}] .
$$

On these values, the inertia force curve is represented, Fig.3.

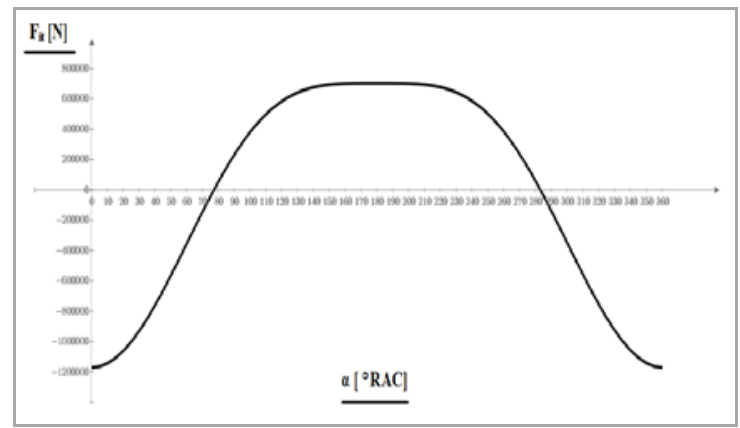

Fig. 3. - The inertia force curve of the masses related to the piston.

\section{THE TOTAL FORCE}

The total force acting on the drive mechanism parts is the sum between the pressure force of the motive fluid and the inertia force of the masses with a translation motion:

$$
\mathrm{F}=\mathrm{F}_{\mathrm{p}}+\mathrm{F}_{\text {it }}[\mathrm{N}]
$$

On these values, the total force curve is represented, Fig. 4.

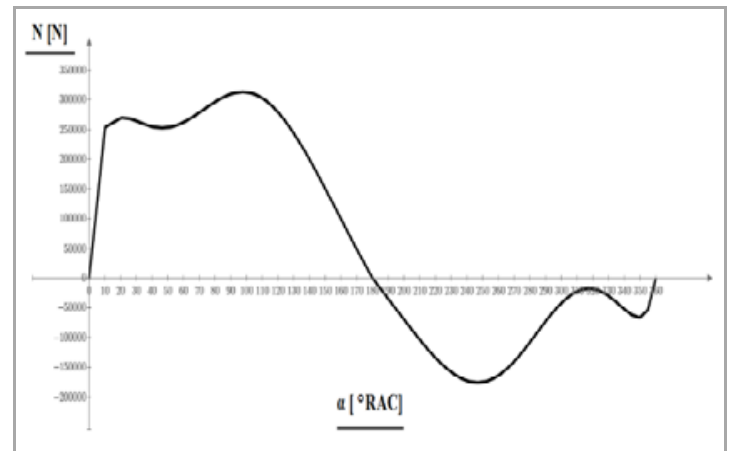

Fig.4. The total force curve.

\section{THE DECOMPOSITION OF THE TOTAL FORCE}

The determination of the longitudinal and normal components:

1. In the triangle $F O B$, the longitudinal component:

$\mathrm{B}=\frac{\mathrm{F}}{\cos (\beta)}[\mathrm{N}]$

2. In the triangle FON, the normal componet:

$\mathrm{N}=\operatorname{tg}(\beta) \cdot \mathrm{F}[\mathrm{N}]$

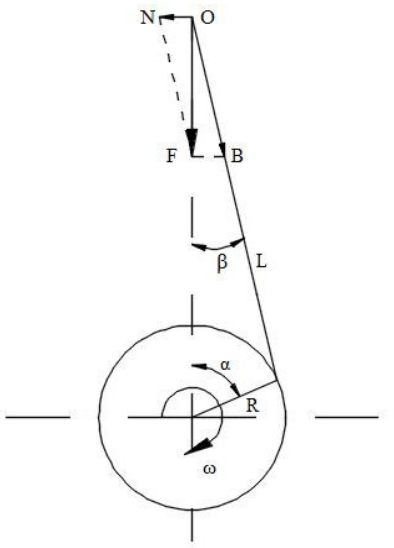

Fig.5. The decomposition of the total force into the longitudinal and normal components.

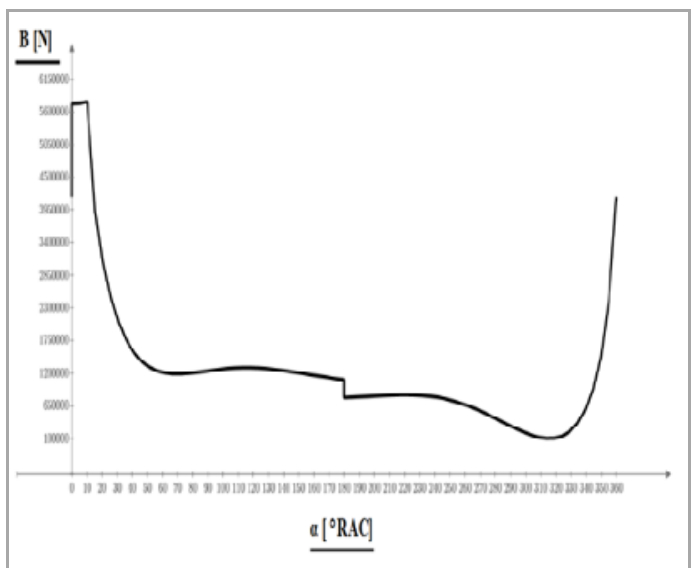

Fig.6. The longitudinal force curve.

The longitudinal component is the force resulted by the decomposition of the total force acting along the connecting-rod axis.

The normal component is the force resulted by the decomposition of the total force acting perpendicular to the cylinder axis, represented in fig.7. 
"Mircea cel Batran" Naval Academy Scientific Bulletin, Volume XX - 2017 - Issue 1

The journal is indexed in: PROQUEST / DOAJ / Crossref / EBSCOhost / INDEX COPERNICUS / DRJI / OAJI I

JOURNAL INDEX I I2OR / SCIENCE LIBRARY INDEX / Google Scholar I Academic Keys/ ROAD Open Access I Academic Resources / Scientific Indexing Services / SCIPIO / JIFACTOR

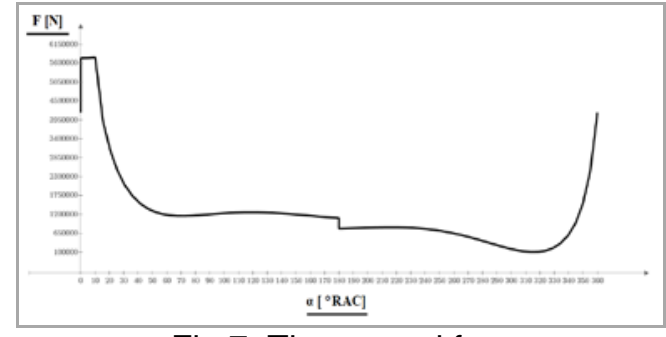

Fig.7. The normal force curve.

\section{THE DECOMPOSITION OF THE LONGITUDINAL FORCE}

The determination of the radial and tangential components fig.8:

1.In the triangle $\mathrm{BOZ}_{\mathrm{B}}$, the radial component:

$$
Z_{B}=\cos (\alpha+\beta) \cdot B
$$

The values of the radial force $\left(Z_{B}\right)$ have been calculated and on these values, the radial force curve is represented in fig. 9 .

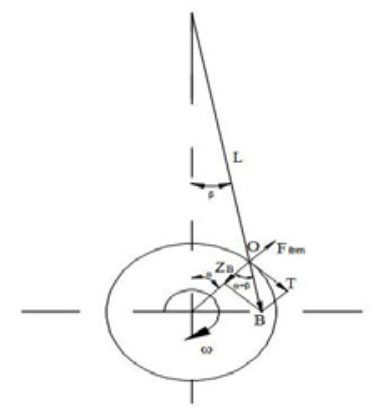

Fig.8. The decomposition of the longitudinal force into the radial and tangential components.

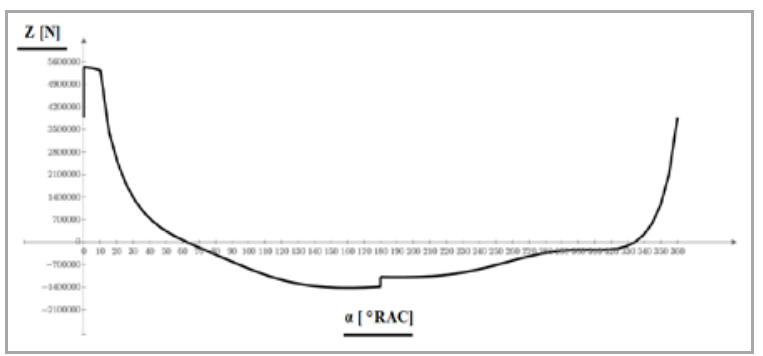

Fig.9. The radial force curve.

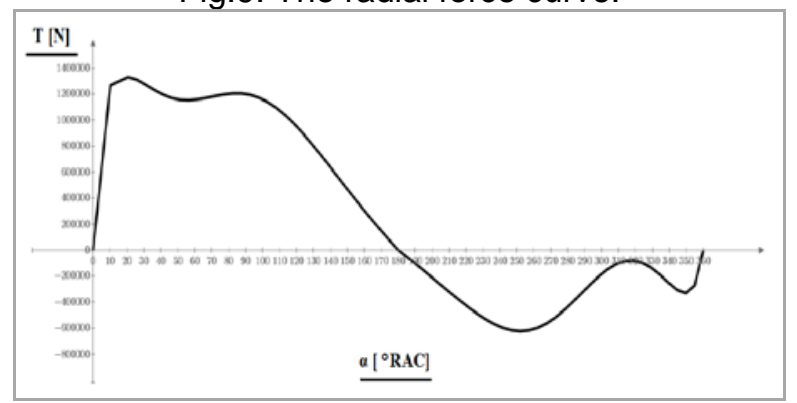

Fig.10. The tangential force curve.
2. In the triangle $\mathrm{BOZ}_{\mathrm{B}}$, the tangential component:

\section{$\mathrm{T}=\sin (\alpha+\beta) \cdot B$}

The values of the tangential force have been calculated and on these values, the tangential force curve is represented, Fig.10.

The total radial component is the sum between the tangential component and the inertia force of the connecting-rod related to the crankpin:

$\mathrm{Z}=\mathrm{Z}_{\mathrm{B}}+\mathrm{F}_{\mathrm{ibm}}$

The values of the total radial force have been calculated and on these values, the total radial force curve is represented in fig. 11 .

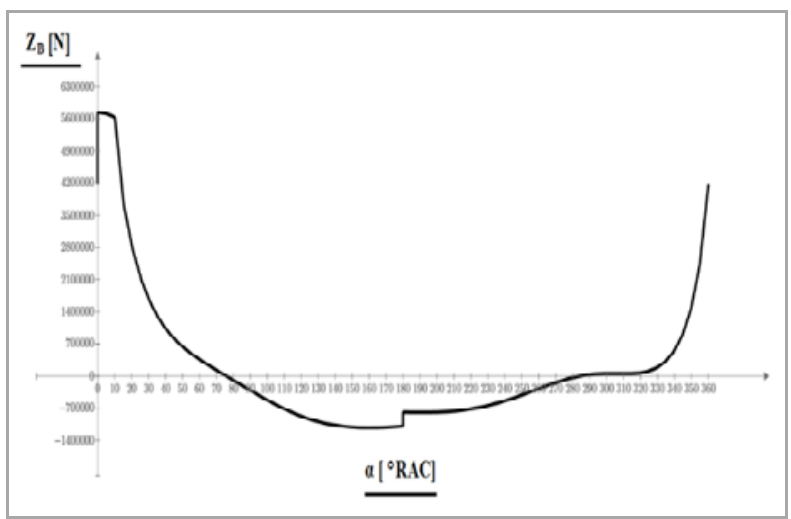

Fig.11. The total radial force curve.

\section{THE DRIVING MOMENT}

The calculation relation of the instantaneous driving moment is:

\section{$\mathrm{M}=\mathrm{T} \cdot \mathrm{R}[\mathrm{N} \cdot \mathrm{m}]$}

The values of the instantaneous driving moment have been calculated and on these values, the total radial force curve is represented in fig. 12.

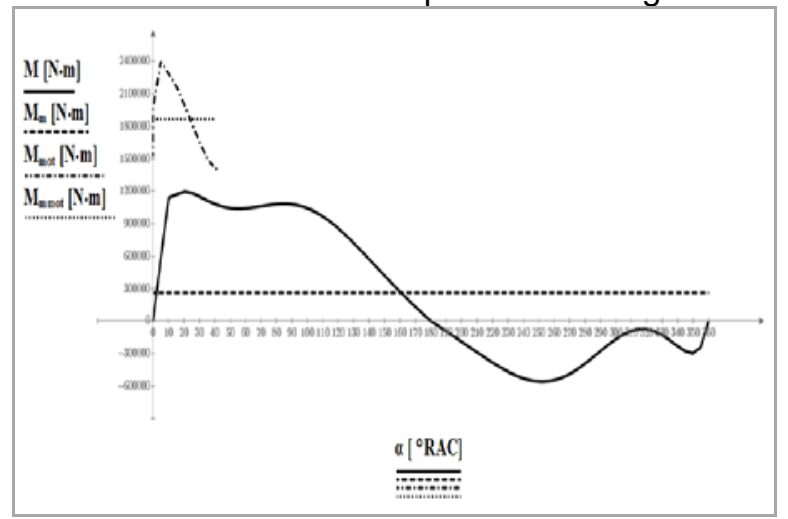

Fig.12. The variation of the driving moments induced in the driver. 
"Mircea cel Batran" Naval Academy Scientific Bulletin, Volume XX - 2017 - Issue 1

The journal is indexed in: PROQUEST / DOAJ / Crossref / EBSCOhost / INDEX COPERNICUS / DRJI / OAJI I

JOURNAL INDEX I I2OR / SCIENCE LIBRARY INDEX / Google Scholar I Academic Keys/ ROAD Open Access I

Academic Resources / Scientific Indexing Services / SCIPIO / JIFACTOR

\section{Conclusions}

This paper presents a numerical method for determining the stresses by means of the E-FORT program with MATHCAD as a mathematical interpreter. It can be used for determining the stresses in the drive mechanism of the slow and semi-fast marine engines, being useful in every day practice for the determination of the untimely wears of the drive mechanism system.

\section{Bibliography}

[1] Alexandru C.; Maşini şi instalaţii navale de propulsie, Editura Tehnică, Bucureşti p. 44-56, (1991).

[2] Grunwald B.; Teoria, calculul şi construcţia motoarelor pentru autovehicule rutiere, Editura Didactică şi Pedagogică, Bucureşti, p 123-134, (1980).

[3] Dragalina Al.; Aplicaţii de calcul ale motoarelor diesel navale, Academia Navală "Mircea cel Bătrân", Constanţa,, p. 54-60, (1993).

[4] Moroianu C.. S.a. (1997).Motoare Diesel , Editura Didactică şi Pedagogică, Bucureşti, p 131-134, (1996). 